\title{
Morphometric and Ultrastructural Studies in an Infant with Leucine-Sensitive Hypoglycemia, Hyperinsulinism and Islet Hyperplasia*
}

\author{
G. Klöppel, E. Altenähr, W. Reichel, R. Willig and G. Freytag \\ Institute of Pathology and Department of Pediatrics, University of Hamburg: \\ Received: August 14, 1973, in revised form: March 11, 1974
}

Summary. Morphometric and ultrastructural studies were performed on biopsy material from the pancreas of an infant with severe leucine-sensitive hypoglycemia and hyperinsulinism, in whom no insulinoma had been found. Qualitatively many large B cells were observed within the pancreatic islets. Quantitatively an about two fold increase of islet tissue proportion (4.2\%) was demonstrated, compared with controls of approximately the same age $(1.8 \%)$. Differential islet cell counting revealed an increase in $A_{1}$ cells whereas the percentage of $A_{2}$ and $B$ cells appeared to be unchanged. Ultrastructurally in addition to $\mathrm{A}, \mathrm{B}$, and $\mathrm{D}$ cells a fourth islet cell type was demonstrated in unusual frequency. Its general function and its particular significance for the hypoglycemic syndrome are unknown. The findings correspond well with recent observations on the islet cell system in cases of neonatal hypoglycemia with leucine-sensitivity and hyperinsulinism.

Key words: Neonatal hypoglycemia, hyperinsulinism, leucine-sensitivity, islet hyperplasia, ultrastructure, A, B, D and type IV cells.
Reports concerning histopathology $[3,4,8,9,16$, $17,18]$ or ultrastructure [26] of the pancreatic islets in idiopathic neonatal hypoglycemia are rare. Most of the examined pancreata showed a regular islet system [18], whereas only few exhibited islet hyperplasia. Moreover, as quantitative methods were only rarely applied to islet examination in infants, the diagnosis of islet hyperplasia as a cause of neonatal hypoglycemia remained often doubtful.

A recent report of Misugi and coworkers [26] renewed the interest in the islet system in neonatal hypoglycemia. The authors described islet cell hyperplasia in three infants with leucine-sensitive hypoglycemia [4] and hyperinsulinism. The ultrastructural examination revealed a fourth islet cell type in addition to $\mathrm{A}, \mathrm{B}$ and $\mathrm{D}$ cells. The present report of a case of leucine-sensitive neonatal hypoglycemia confirms the findings of Misugi and associates, and briefly discusses the significance of the observations on the basis of the literature on this subject.

\section{Case Report}

A female infant was born spontaneously with a birth weight of $4550 \mathrm{~g}$. Two siblings were normal. There is no family history of diabetes mellitus. The mother showed a normal oral glucose tolerance test at the sixth day post partum. At two days of age the newborn was admitted to hospital because of sudden areflexia, unconsciousness and generalized cyanosis with snapping breathing. Routine blood glucose determinations revealed hypoglycemic values ranging between $3 \mathrm{mg} \%$ and $60 \mathrm{mg} \%$. The hypoglycemic episodes occurred in the fasting state as well as after administration of glucose and prednisone. Labora. tory tests including glucagon stimulation test (see Table 1)

* This work has partly been presented at the VIII. Congress of the International Diabetes Foderation, Brussels, 1973 (12). and analysis of certain amino acids ${ }^{1}$ in blood and urine were within normal limits. Tests for extrainsular endocrine disorders, in particular of the pituitary and the adrenals, revealed no defects. A 2-deoxy-d-glucose test for excluding a defective epinephrine response to insulin-induced hypoglycemia was not done [32]. The intravenous administration of L-leucine $(150 \mathrm{mg} / \mathrm{kg})$ caused a $50 \%$ drop in blood glucose $15 \mathrm{~min}$ after injection (see Table 1). Immuno-

Table 1. a) Blood glucose values during different tests in an infant with leucine-sensitive hypoglycemia. b) Serum immunoreactive insulin (IRI) during hypoglycemic episodes. Normal range of blood glucose: $48-103 \mathrm{mg} / 100 \mathrm{ml}$. Normal range of IRI in children: $2-21 \mu U / m l$ (33), and in adults : $8-30 \mu U / m l$

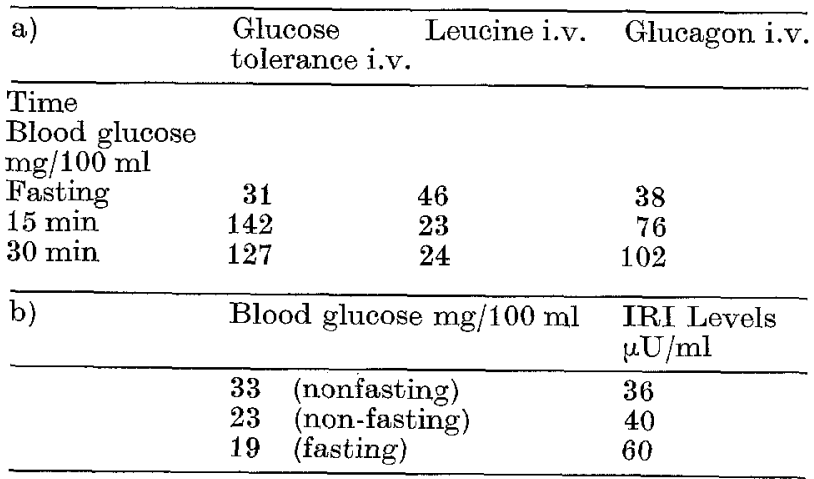

reactive serum insulin (amberlite adsorption method [25]) concentrations obtained during hypoglycemic episodes in fasting and non-fasting states were found to be above normal fasting values in children $(2-21 \mu \mathrm{U} / \mathrm{ml}$ [33]) and even in adults $(8-30 \mu \mathrm{U} / \mathrm{ml}$ ) (see Table 1). Roentgenographic studies revealed a possible tumour at the upper pole of the right kidney. On exploratory laparotomy, when the infant was at the age of 6 months, neither a

1 (Hydroxyproline, threonine, serine, alanine, valine, leucine, tyrosine, phenylalanine, lysine, histidine, arginine). 
tumour of the pancreas nor of the kidney was found. At operation tissue from the corpus-cauda pancreatis $(0.7 \times$ $0.4 \times 0.3 \mathrm{~cm}$ ) was removed for histological and ultrastructural examination. Subsequently the infant was treated with a diet poor in leucine, with diazoxide and primidone. With this therapy hypoglycemia only occasionally occurred, while the mental impairment showed no improvement.

\section{Material and Methods}

The pancreatic tissue was treated as follows: for light microscopy it was fixed in Bouin's fixative. Serial sections were stained with hematoxylin-eosin, Periodic Acid Schiff (PAS), Gomori's aldehyde fuchsin, the silver impregnation technique according to Hellerström and Hellman [19], phosphotungstic acid hematoxylin (PTAH), and Azan-Mallory trichrome. For electron microscopy the tissue was immediately fixed following removal by immersion in 3\% glutaraldehyde buffered with $0.1 \mathrm{M}$ sodium cacodylate $(\mathrm{pH}$ 7.4) for two hours. After rinsing in $0.1 \mathrm{M}$ sodium cacodylate buffer the cubes were postfixed in $1 \%$ osmium tetroxide buffered with 0.1 sodium cacodylate for $90 \mathrm{~min}$. The fixed tissue was dehydrated in graded ethanol and after passing propyleneoxide embedded in Epon 812. Ultrathin sections were cut on a Reichert ultramicrotome Om U2, double stained with uranyl acetate and lead citrate, and examined in a Philips electron microscope EM 300 at $60 \mathrm{kV}$.

For estimation of the proportion of the islet tissue in the pancreatic parenchyma 300 different fields were evaluated in three consecutive sections of $300 \mu$ distance, each measuring $125600 \mu^{2}$, by means of the formula $\mathrm{IA} \times 100 / \mathrm{FA}$. IA means the islet area in the evaluated sections, FA the total area evaluated in the sections. The areas of the single islets $\left(\mathrm{IA}_{\mathrm{s}}\right)$ were calculated by the formula $\mathrm{IA}_{\mathrm{s}}=\frac{\pi}{4} \mathrm{~d} \times \mathrm{D}$ (d: smallest diameter of the islet; $D$ : largest diameter of the islet) and finally summed up to the total islet area. Furthermore, the average frequency of the islets was calculated from the number of islets of each field evaluated in the sections. For differential islet cell counting 1500 cells were counted with the nucleus as counting base. This was done on three consecutive sections ( $3 \mu$ thick) stained with Gomori's aldehyde fuchsin (B cells), the silver impregnation technique [19] $\left(\mathrm{A}_{1}\right.$ cells) and PTAH ( $\mathrm{A}_{2}$ cells). Differential islet cell counting was also performed at the ultrastructural level with the nucleus as counting base. 500 cells were counted. For comparison of the results from the quantitative studies of the islet cell system in the present case, post mortem pancreatic tissue of 10 infants, aged 4 to 8 months, were evaluated in the same way, as described above. 5 of the infants suffered from congenital heart failures, 3 from leucaemis, 1 from a hemolytic uremic syndrome and 1 died as a result of an accident. The fasting glucose values of all infants were within normal ranges. The pancreatic tissue of these infants, removed within $24 \mathrm{~h}$ after death, was well preserved. It was taken from the corpus-cauda region $(1 \times 1 \times 0.5 \mathrm{~cm})$. No control material was available for electron microscopic studies.

\section{Results}

\section{Light Microscopy}

a) Qualitative observations: the pancreas exhibited extreme islet hyperplasia due to marked increase in the number of islets and the presence of giant islets (see Fig. $1 \mathrm{a}$ and $\mathrm{b}$ ). The largest islet diameter was about $700 \mu$. The small islets were often poorly demarcated. Clusters of islet cells infiltrated between the acinar cells. Occasionally they appeared to bud out from the duct epithelium (see Fig. 1c). Marked hypertrophy of single islet cells in each islet was a typical finding (see Fig. $1 \mathrm{~b}$ and c). Differential staining revealed $A_{1}, A_{2}$ and $B$ cells. The hypertrophied islet cells represented $B$ cells (see Fig. 2). Some of the $A_{1}$ and $B$ cells were only sparsely granulated.

b) Quantitative observations (see Table 2): the proportion of the islet tissue in the pancreatic parenchyma was $4.2 \%$ (controls: 1.3 to $3.0 \%$ with a mean value of $1.8 \%$ ). The frequency of islets in the pancreatic tissue of the hypoglycemic infant was 4.7 (controls: 1.0 to 3.2 with a mean value of 2.2 ). $A_{1}$ cells comprised $42 \%, A_{2}$ cells $13 \%$, and $B$ cells $45 \%$ of the total islet cell mass. About $10 \%$ of the $B$ cells were hypertrophied and corresponded to the large clear cells observed in the PAS-stained sections. In the controls, $20-35 \%$ (mean value $24 \%$ ) were classified as $A_{1}$ cells, $10-20 \%$ (mean value $18 \%$ ) as $A_{2}$ cells and $50-$ $60 \%$ (mean value $57 \%$ ) as $\mathrm{B}$ cells.

\section{Electron Microscopy}

Ultrastructurally typical islet cell formations as well as clusters of few endocrine cells in between acinar cell complexes were observed. A transformation of exocrine into endocrine cells, suggested from the first light microscopical examination [12], could not be confirmed. There were sometimes difficulties in distinguishing duct cells and endocrine cells which were poorly granulated. Four types of islet cells, i.e. A, B, $\mathrm{D}$ and so called type IV cells $[6,7]$, were identified (see Fig. 3).

Fig. 1. Islet hyperplasia in an infant with neonatal leucine-sensitive hypoglycemia. a) Marked increase in the number of islets with hyperplasia of single islets and diffuse infiltration of islet cell complexes between the acinar tissue. PAS $\times 37$. b) Giant islet with extreme hypertrophy of single cells. PAS $\times 115$. c) Clusters of islet cells, partly with hypertrophic nuclei, between acinar tissue, and budding out from duct epithelium $(\uparrow)$. PAS $\times$ 
$1 \mathrm{a}$
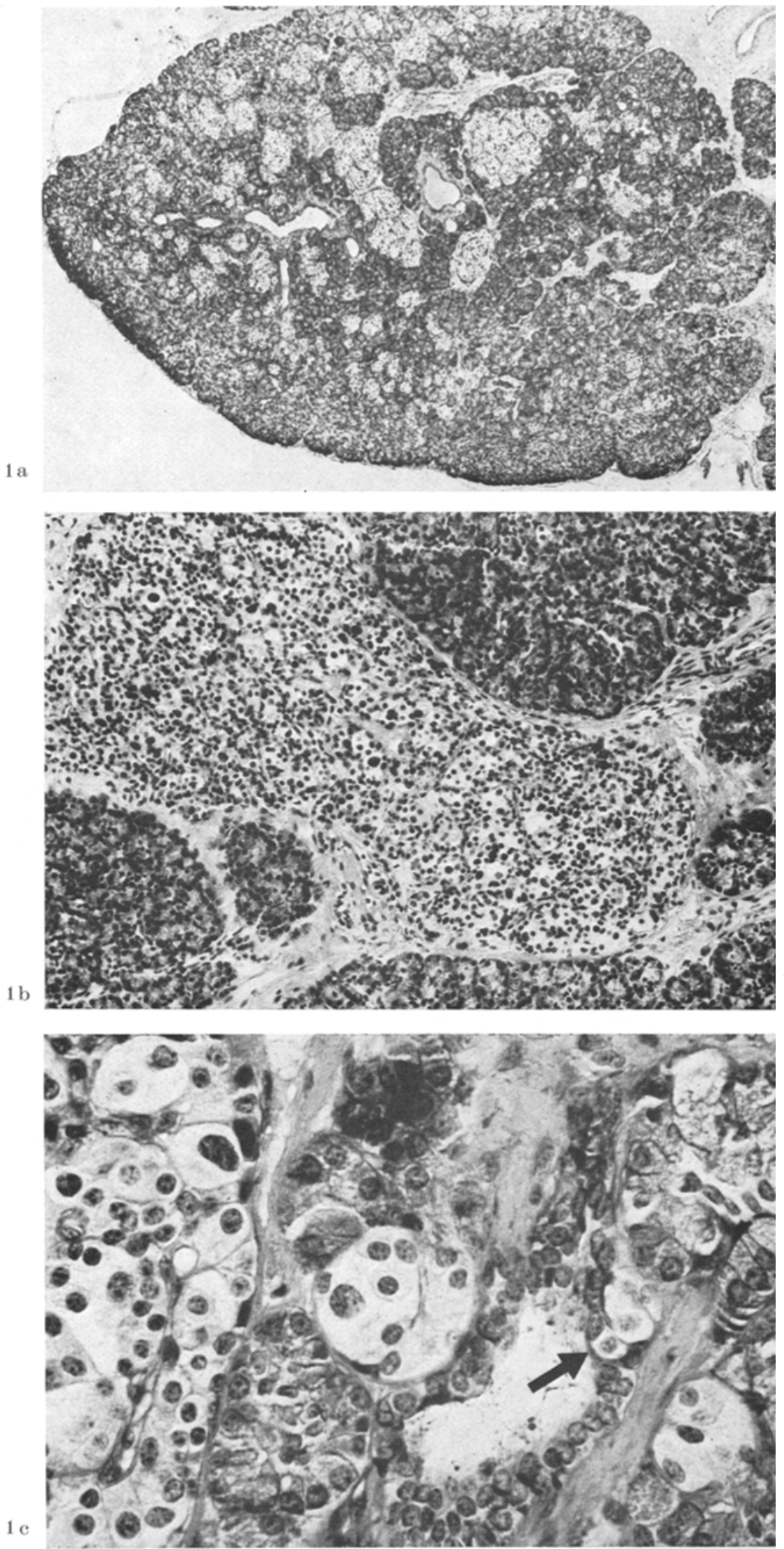
A cells showed the typical picture as it is known from the literature $[2,20,22,23,38]$. The eccentric cores of the granules were markedly electron dense (range of diameter 150 to $400 \mathrm{~m} \mu$ ). No signs of activation were present. The A cells comprised $13 \%$ of the islet cells.

B cells characterized by their granules (range of diameter 350 to $500 \mathrm{~m} \mu$ ) with either polymorphous or spheric cores showed varying granulation. In some B cells there were prominent Golgi complexes, surrounded by many microvesicles, and well developed structures of rough endoplasmic reticulum. Single B cells were found between acinar cells and adjacent to duct cells. The B cells represented $43 \%$ of the islet cells.

The fine structure of $D$ cells was in accordance with the structural features of this cell type known from the

Table 2. Quantitative estimations of the proportion of islet tissue and islet cells in an infant with leucine-sensitive hypoglycemia, and in 10 controls (post mortem material) aged 4 to 8 months. S.D.-Standard deviation

\begin{tabular}{|c|c|c|c|c|c|}
\hline & \multirow{2}{*}{$\begin{array}{l}\text { Percentage } \\
\text { of islet } \\
\text { tissue in the } \\
\text { pancreas }\end{array}$} & \multirow{2}{*}{$\begin{array}{l}\text { Frequency } \\
\text { of islets per } \\
\text { visual field }\end{array}$} & \multicolumn{3}{|c|}{ Differential islet cell counting } \\
\hline & & & $A_{1}$ & $A_{2}$ & $\mathrm{~B}$ \\
\hline $\begin{array}{l}\text { Infant with } \\
\text { hypoglycemia }\end{array}$ & 4.2 & 4.7 & $42 \%$ & $13 \%$ & $45 \%$ \\
\hline $\begin{array}{l}\text { Controls } \\
(n=10) \\
\text { mean value }\end{array}$ & $\begin{array}{l}1.8 \\
(1.3-3.0) \\
\text { S.D. } 0.62\end{array}$ & $\begin{array}{l}2.2 \\
(1.0-3.2) \\
\text { S.D. } 0.70\end{array}$ & $\begin{array}{l}24 \% \\
(20-35 \%)\end{array}$ & $\begin{array}{l}18 \% \\
(10-20 \%)\end{array}$ & $\begin{array}{l}57 \% \\
(50-60 \%)\end{array}$ \\
\hline
\end{tabular}

Table 3. Summary of cases with neonatal hypoglycemia and proved islet hyperplasia since 1956

\begin{tabular}{lllll}
\hline Authors & $\begin{array}{l}\text { Number of } \\
\text { cases }\end{array}$ & $\begin{array}{l}\text { Serum } \\
\text { insulin }\end{array}$ & $\begin{array}{l}\text { Leucine- } \\
\text { sensitivity }\end{array}$ & $\begin{array}{l}\text { Ultrastructural } \\
\text { characteristics }\end{array}$ \\
\hline Cochrane et al., 1956 & 1 & $\uparrow$ & - & - \\
Douglas, 1959 & 1 & $\uparrow$ & $?$ & - \\
Haworth and Coodin, & & $?$ & - & - \\
1960 & 1 & $?$ & + & - \\
Haddad et al., 1962 & 1 & $\uparrow$ & + & - \\
Brown and Young, 1970 & 1 & $\uparrow$ & + & Type IV cell \\
Misugi et al., 1970 & 3 & & & hyperplasia \\
\hline
\end{tabular}
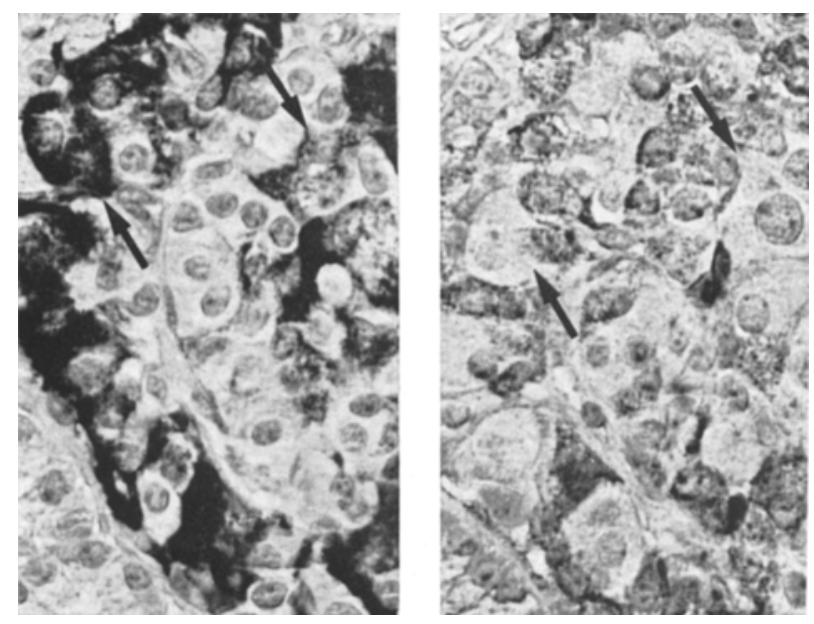

Fig. 2. Differential islet cell staining in two consecutive sections with Gomori's aldehyde fuchsin method (left) and the silver impregnation technique according to Hellerström-Hellman (right) showing that the hypertrophic cells $(\uparrow)$ represent $B$ cells. $\times 500$ literature $[2,6,7,14,21,23,34,38]$. They constantly contained numerous large granules of low electron density (range of diameter $300-700 \mathrm{~m} \mu$ ). The $\mathrm{D}$ cells comprised $19 \%$ of the islet cells.

The so called type IV cells $[6,7]$ were characterized by their granules (see Fig. 3). The size of the granules was within the same range as of $A$ cell granules $(150-$ $400 \mathrm{~m} \mu$ ), but the homogenous, electron dense cores were not eccentrically arranged in the granules. Many of the type IV cells, generally tending to be larger than A cells, were hypogranulated (see Fig. 4). These cells mostly contained only few mitochondria, small sacs of smooth and rough surfaced endoplasmic reticulum, some free ribosomes and small Golgi complexes. Well granulated type IV cells often showed abundant organelles. Type IV cells were located throughout the islets or between acinar cells (see Fig. 5) and adjacent to duct cells. Single cells were also observed within the interstitial tissue, where they were sometimes found to be in close contact to unmyelinated nerve fibres. The type IV cells comprised $24 \%$ of the islet cells. 


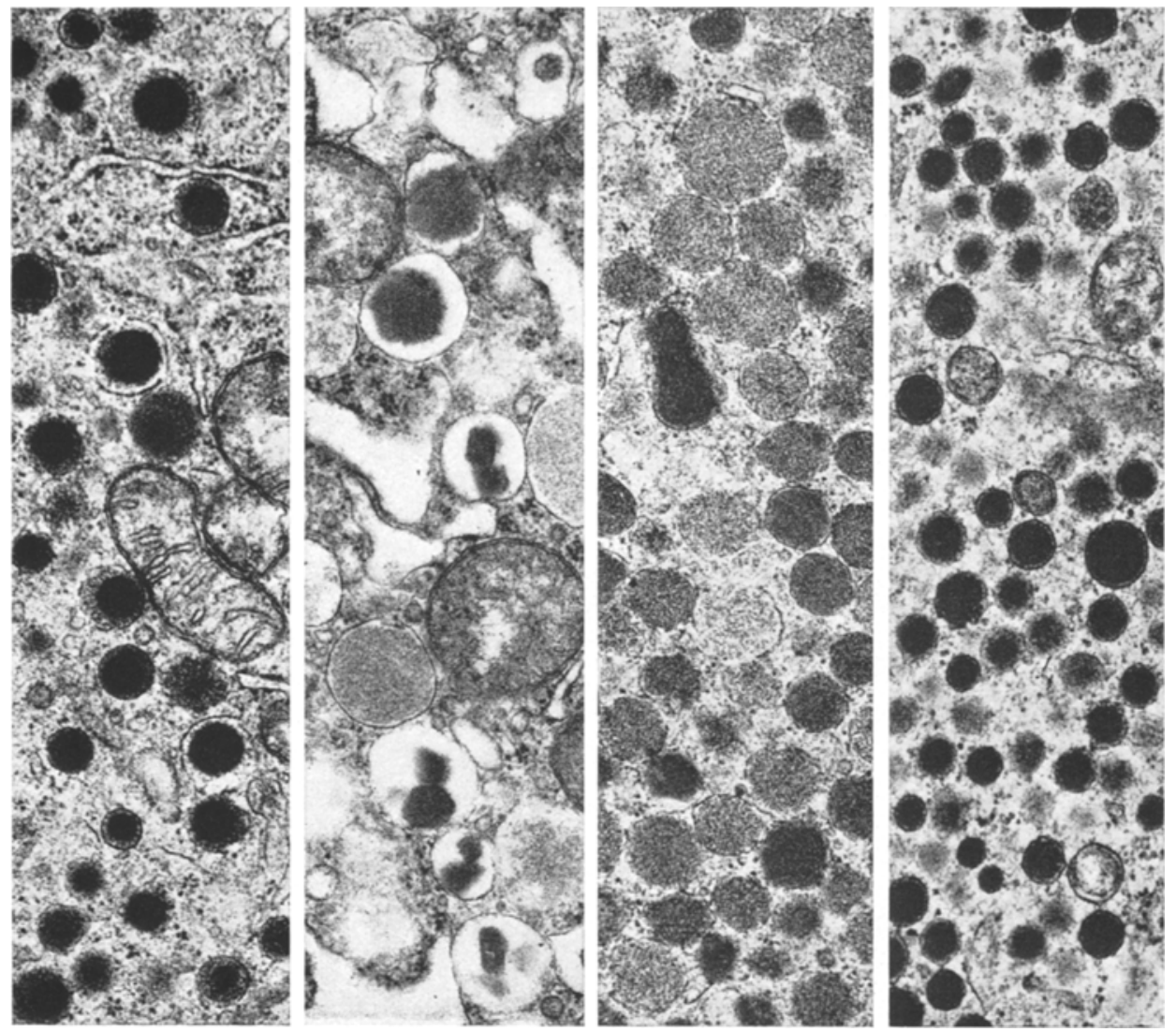

Fig. 3. Comparison of the A cell, B cell, D cell, and type IV cell granules (from left to right). $\times 18790$

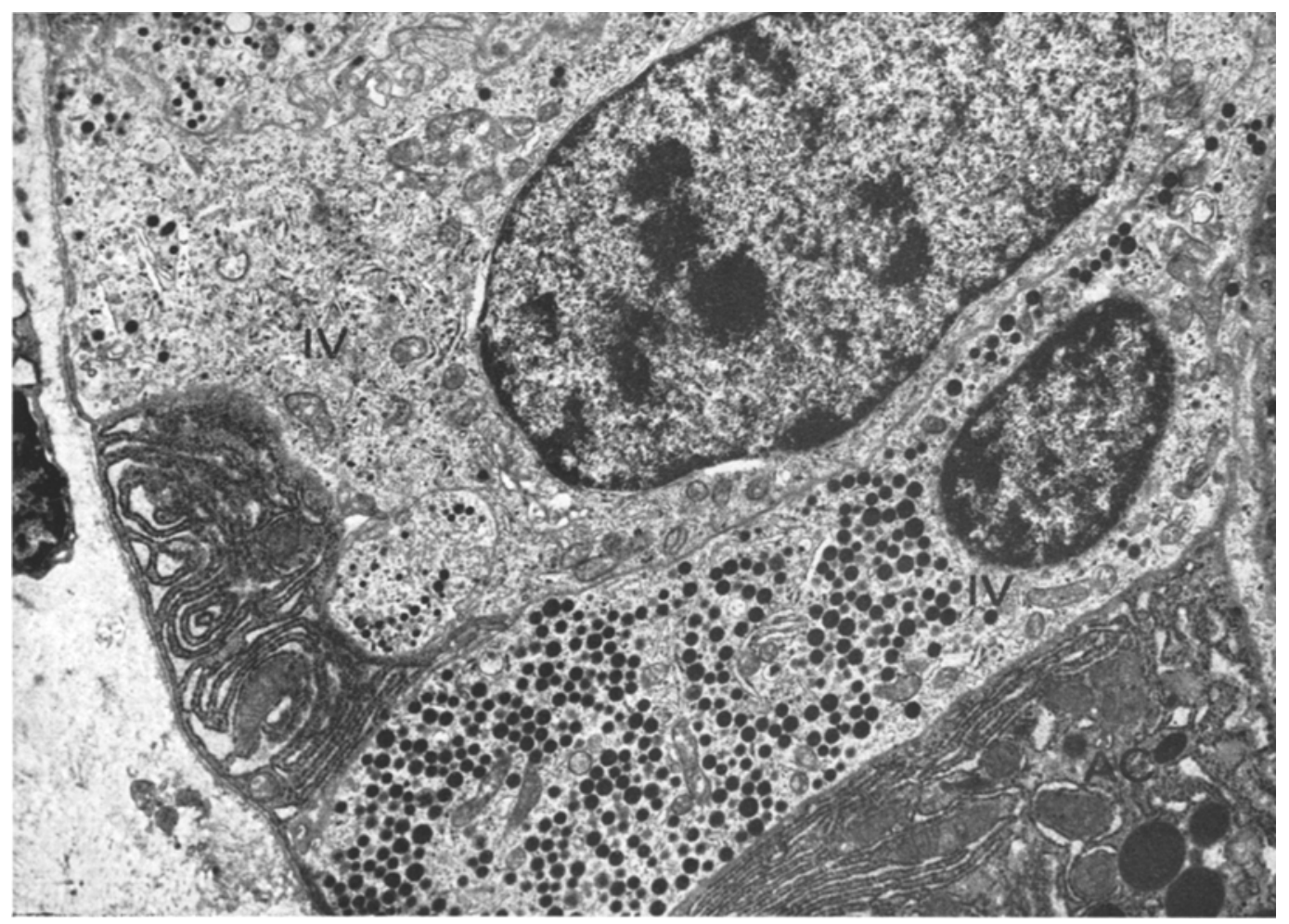

Fig. 4. Two type IV cells (IV). Note the different content of secretory granules. (AC) Acinar cells. $\times 7583$ 


\section{Discussion}

Morphometric studies of a biopsy specimen from the pancreas of an infant with leucine-sensitive hypoglycemia and hyperinsulinism revealed marked islet hyperplasia and islet cell hypertrophy. The percentage distribution of the islet tissue in the pancreatic parenchyma was about twice that of controls. Moreover, there was an increase in $A_{1}$ cells, whereas the percentage of $\mathrm{A}_{2}$ and $\mathrm{B}$ cells was found to be unchanged.

These observations, however, are limited by the fact that only a small piece of the pancreas was histolo- earlier reports on this subject $[4,9,16,3]$. Summarizing the findings in these cases, they seem to share the following characteristics (see Table 3): clinically, a hyperinsulinism in fasting and non-fasting states and often leucine-sensitivity can be demonstrated. Histopathologically, giant islets, numerous clusters of islet cells among acinar cells and adjacent to ducts, and islet cell hypertrophy are present. Furthermore, it is emphasized in some reports $[16,26]$ that the large cells were often agranular. In the present case true agranular cells were not observed with certainty. All islet cells, though sometimes poorly granulated, could

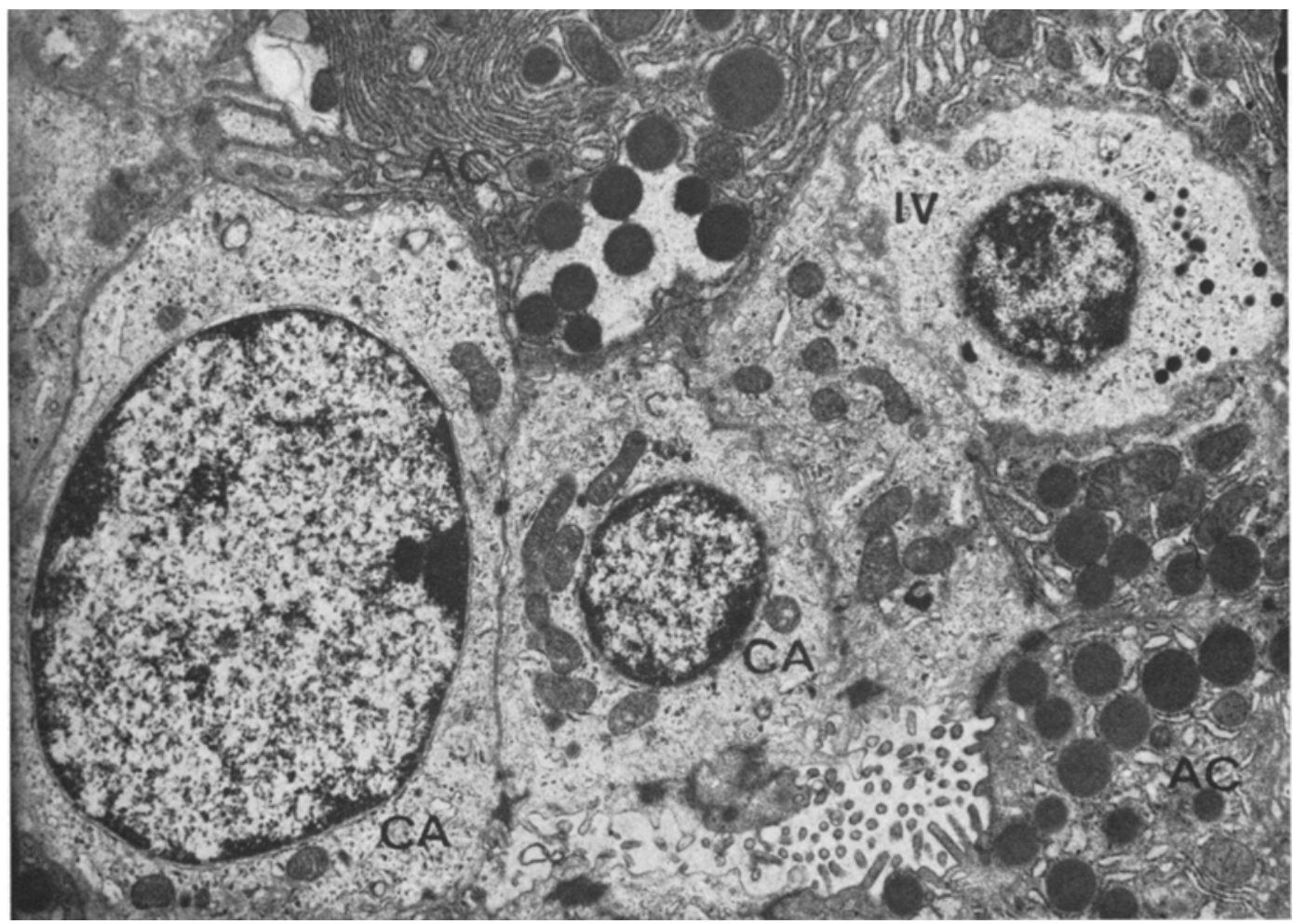

Fig. 5. Type IV cell (IV) in close contact with acinar (AC) and centro-acinar cells (CA). $\times 7583$

gically examined. Whether the same qualitative and quantitative findings are also present in the rest of the pancreas, remains therefore uncertain. Thus it can't be totally excluded that an insulinoma has been overlooked, although the pancreas had been carefully investigated at operation. Insulinomas in. infancy are rare but have to be considered $[29,30]$. In the case presented, hypoglycemic episodes occurred not only postprandial but also in fasting states which are indicative of an insulinoma.

On the other hand, the case seems to have similarities with a report of Misugi and coworkers [26] who demonstrated islet hyperplasia and islet cell hypertrophy in three infants with severe hypoglycemia in fasting and non-fasting states. It also parallels single be classified either as $B$ cells (large and medium size cells), $A_{1}$ cells (medium size cells) or $A_{2}$ cells (small cells) by their staining characteristics and their fine structure. As some of the large $B$ cells were only sparsely granulated, it may be suggested that the hypertrophic agranular cells of the other authors probably represented hypogranulated B cells [26]. Experimentally, the so called agranular cell type II [10] of the proliferating islet cell system in duct ligated rats with alloxan diabetes might correspond to these hypogranulated B cells.

Electron microscopy of the cases of Misugi and coworkers [26] and of the present case revealed in addition to typical $A, B$, and $D$ cells a high number of a fourth islet cell type, the so called type IV cell $[6,7]$, 
which is particularly characterized by its small spherical granules. Some of these cells were hypogranulated, and were found within interstitial and acinar areas. The function of these cells is still a matter of speculation. Cells with similar granular structures are found in certain insulinomas [5] and gastrinomas [36] (Mitschke, personal communication). They are also thought to have some features in common with $A$ [34], D [2, 28, 31, 37] and gastrointestinal $\mathrm{D}_{1}$ cells [35]. Thus it remains open whether type IV cells represent an independent islet cell type, a precursor cell, or a functional variant of one of the known islet cell types. From the results of the differential cell counting it is assumed that type IV cells together with $D$ cells $[11$, 13] may belong to a heterogenous $A_{1}$ cell group [1], because there was a striking correspondence, when the percentages of $\mathrm{D}$ and type IV cells, found in the electron microscope, were summed ( $43 \%)$, and compared with the percentage of the $A_{1}$ cells $(42 \%)$, light microscopically determined.

The cause of the inappropriate insulin release and of the continued proliferation of the islet cell system in newborn with severe hypoglycemia and hyperinsulinism is unknown. Histopathologically, the large B cells, indicating hyperactivity, and the islet hyperplasia, suggesting an increase in the total number of the $B$ cells, may be considered the morphological equivalent of the hyperinsulinism. Ultrastructurally, however, the hyperactivity of the $B$ cells was not as clear as was expected from the light microscopical pattern. Whether the unusual frequency of type IV cells; which contributed much to the islet hyperplasia, is also a cause of the hyperinsulinism or merely its concomitant re. sult, remains open. Hypermethioninemia [27] which is discussed to be a cause of both hypoglycemia and islet hyperplasia was not excluded in the case presented. The hypothesis that A cell deficiency accounts for hypoglycemia $[15,24]$ seems unlikely, since the A cells were not significantly reduced in number nor structurally altered.

Addendum. In the present case supplementary immunohistologic examination of the pancreatic tissue using anti-insulin and anti-gastrin (Dr. Mitschke) antisera strongly demonstrated insulin, but not gastrin within islet cells.

Acknowledgements. This work has been supported by Deutsche Forschungsgemeinschaft, Sonderforschungsbereich 34 Endocrinology, Hamburg. The authors are grateful to Priv.-Doz. Dr. J. Kühnau (Department of Internal Medicine, Universitiy of Hamburg, Germany) for radioimmunological determination of serum insulin levels. Sincere thanks are also due to Mrs. Katrin Baack and Mrs. Ebba Grabow for skilful technical assistance.

\section{References}

1. van Assche, F.A., Gepts, W.: The cytological composition of the foetal endocrine pancreas in normal and pathological conditions. Diabetologia 7, 434-444 (1971)
2. Björkman, N., Hellerström, C., Hellman, B., Peterson, B.: The cell types in the endocrine pancreas of the human fetus. Z. Zellforsch. 72, 425-445 (1966)

3. Brown, R.E., Young, R.B.: A possible role for the exocrine pancreas in the pathogenesis of neonatal leucine-sensitivity. Amer. J. dig. Dis. 15, 65-72 (1970)

4. Cochrane, W.A., Payne, W.W., Simpkiss, M.J. et al. : Familial hypoglycemia precipitated by amino acids. J. Clin. Invest. 35, $411-422(1956)$

5. Creutzfeldt, W., Arnold, R., Creutzfeldt, C., Deuticke, U., Frerichs, H., Track, N.S.: Biochemical and morphological investigations of 30 hurnan insulinomas. Correlation between the tumour content of insulin and proinsulin-like components and the histological and ultrastructural appearance. Diabetologia 9, 217-231 (1973)

6. Deconinck, J.F., Potvliege, P.R., Gepts, W.: The ultrastructure of the human pancreatic islets. I. The islets of adults. Diabetologia 7, 266-282 (1971)

7. Deconinck, J.F., van Assche, F.A., Potvliege, P.R., Gepts, W.: The ultrastructure of the human pancreatic islets. II. The islets of neonates. Diabetologia 8, 326-333 (1972)

8. DiGeorge, A.M., Auerbach, V.H.: Leucine-induced hypoglycemia. A review and speculations. Amer. J. med. Sci. 240, 792-801 (1960)

9. Douglas, D.M.: Spontaneous hyperinsulinism due to benign hyperplasia of islets cells. Arch. Dis. Childh. 34, $171(1959)$

10. Edström, C., Boquist, L.: Alloxan diabetes in ductligated rats. Acta path. microbiol. scand. 81 A, $1-10$ (1973)

11. Epple, A.: Zur vergleichenden Zytologie des Inselorgans. Verh. dtsch. Zool. Ges. 1963. Ergänz. z. Zool. Anz. 27, $461-470$ (1964)

12. Freytag, G., Altenähr, E., Willig, R.P., Klöppel, G.: Extreme islet cell hyperplasia with hyperinsulism in neonatal leucine-sensitive hypoglycemia. VII. Int. Congr. Diabetes Fed., Brussels, 1973. Excerpta Med. Congr. Ser. 280, 487 (1973)

13. Fujita, T.: D cell, the third endocrine element of the pancreatic islet. Arch. Histol. Jap. 29, 1 - 40 (1968)

14. Greider, M.H., Bencosme, S.A., Lechago, J.: The human pancreatic islet cells and their tumors. $\mathrm{I}$. The normal pancreatic islet. Lab. Invest. 22, 344-354 (1970)

15. Grollman, A., McCales, W.E., White, F.N.: Glucagon deficiency as a cause of hypoglycemia. Metabolism 13 . $686-690$ (1964)

16. Haddad, H.M., Roberts, W.C., Pronove, P., Bartter, F.C.: Leucine-induced hypoglycemia. New Engl. J. Med. 267, 1057-1060 (1962)

17. Hamilton, J.P., Baker, L., Kaye, R., Koop, C.E.: Subtotal pancreatectomy in the management of severe persistent indiopathic hypoglycemia in children. Pediatrics 39, $49-58(1967)$

18. Haworth, J.C., Coodin, F.J.: Idiopathic spontaneous hypoglycemia in children. Report of seven cases and review of the literature. Pediatries $25,748-765$ (1960)

19. Hellerström, C., Hellman, B.: Some aspects of silver impregnation of the islets of Langerhans in the rat. Acta endocr. (Kbh.) 35, 518-532 (1960)

20. Hellman, B.: The development of the mammalian endocrine pancreas. Biol. Neonat. 9, $263(1965 / 66)$

21. Lacy, P.E.: Pathology of the islets of Langerhans, in Pathology Annual. Ed.: Sommers, S.C. 1, 352-370. New York: Appleton-Century-Crofts 1966 ,

22. Lacy, P.E.: The pancreatic beta cell: Structure and function. New Engl. J. Med. 276, 187-194 (1967) 
23. Like, A.A.: The ultrastructure of the secretory cells of the islets of Langerhans in man. Lab. Invest. 16, 937-951 (1967)

24. McQuarrie, I.: Idiopathic spontaneously occurring hypoglycemia in infants. Amer. J. Dis. Childh. 87, $399-428$ (1954)

25. Melani, F., Ditschuneit, H., Bartelt, K.M., Friedrich, H., Pfeiffer, E.F.: Über die radio-immunologische Bestimmung von Insulin im Blut. Klin. Wschr. 43, $1000-1007$ (1965)

26. Misugi, K., Misugi, N., Sotos, J., Smith, B.: The pancreatic islet of infants with severe hypoglycemia. Arch. Path. 89, 208-220 (1970)

27. Perry, T.L., Hardwick, D.F., Dixon, G.H., Dolman, C.L., Hansen, S.: Hypermethioninemia: A metabolic disorder associated with cirrhosis, islet cell hyperplasia, and renal tubular degeneration. Pediatrics 36, $236-250(1965)$

28. Potet, F., Martin, E., Thiery, J.P., Bader, J.P., Bonfils, S., Lambling, A.: Etude histologique et cytologique du pancréas endocrine tumoral et non tumoral dans le syndrome de Zollinger-Ellicon. Rev. int. Hépat. 16, 737-761 (1966)

29. Salinas, E.D., Mangurten, H.H., Roberts, S.S., Simon, W., Cornblath, M.: Functioning islet cell adenoma in the newborn. Report of a case with failure of diazoxide. Pediatrics 41, 646-653 (1968)

30. Schwartz, J.F., Zwirren, G. T. : Islet cell adenomatosis and adenoma in an infant. J. Pediat. 79, 232-238 (1971)

31. Shibasaki, S., Ito, T.: Electron microscopic study on the human pancreatic islets. Arch. histol. jap. 31, $119-154(1969)$
32. Sizonenko, P.C., Terraz, M., Valloton, M. B., Zahnd, G., Paunier, L.: Assesment of adrenal medulla response to 2-deoxy-D-glucose in idiopathic hypoglycaemia of childhood. Europ. J. clin. Invest. 2, $307-308$ (1972)

33. Slone, D., Soeldner, J.S., Steinke, J., Crigler, J.F. Serum insulin measurements in children with idiopathic spontanoous hypoglycemia and in normal infants, children and adults. New Engl. J. Med. 274, $820-826(1966)$

34. Thiery, J.P., Bader, J.P.: Ultrastructure des islets de Langerhans du Pancreas Humain. Normal et Pathologique. Ann. Endoer. 27, 625 -647 (1966)

35. Vasallo, G., Capella, C., Solcia, E.: Endocrine cells of the human gastric mucosa. Z. Zellforsch. 118, 49-67 (1971)

36. Vasallo, G., Solcia, E., Bussolati, G., Polak, J.M., Pearse, A.G.E.: Non-G cell gastrin-producing tumours of the pancreas. Virch. Arch. Abt. B Zellpath. 11, 66-79 (1972)

37. Weichert, R.F., Roth, L.M., Harkin, J.C.: Carcinoidislet cell tumor of the duodenum and associated multiple carcinoid tumors of the ileum. An electron microscopic study. Cancer (Philad.) 27, 910-918 (1971)

38. Wellmann, K.F., Volk, B.W., Brancato, P.: U7trastructure and insulin content of the endocrine pancreas in the human foetus. Lab. Invest. 25, 97-103 (1971)

Dr. G. Köppel

Pathologisches Institut der Universität D-2000 Hamburg 20

Martinistr. 52

Federal Republic of Germany

\section{Corrigendum Notice}

Diabetologia 10, 53-59 (1974). G. Devis et.al.: Dynamics of Insulin Release and Microtubular-Microfilamentous System.

p. 54, 2nd column, section 2, lines 13-14: complete the sentence as follows "no enhancement of glucose-induced insulin release was anymore noted".

p. 58, 1st column, section 3, line 8: supress the comma after "possibly".

\footnotetext{
Responsible for the text: Prof. Dr. W. CReutzfeld, Med. Universitätsklinik, Humboldtallee 1, D-34 Göttingen/F.R.G. Prof. Dr. K. Schöff'LING, Zentrum der Inneren Medizin, Theodor-Stern-Kai 7, D-6 Frankfurt 70/F. R. G. Responsible for advertisements: L. Silitet, G. Martin, D-1000 Berlin 15, Kurfürstendamm 237. Springer-Verlag, Berlin, Heidelberg. New York. Printed in Germany by Druckerei Georg Appl, Wemding/Schwaben. Copyright (C) by Springer-Verlag Berlin - Heidelberg 1974
} 